ГНУ ВНИИЗБК, 2010. - 268 с.

3. Столяров О.В., Федотов В.А., Демченко Н.И. Нут (Cicer arietinum L.): Монография. - Воронеж: Изд-во Воронежского государственного университета, 2004. - 256 с.

4. Muehlbauer F.J., Tullu A. Cicer arietinum L. NewCROP FactSHEET // http://www.hort.purdue.edu/newcrop/cropfactsheets/Chickpea.html, 1997.

5. Altaf N., Ahmad M.S. Chickpea (Cicer arietinum L.) // Biotechnology in Agriculture and Forestry. Vol. 10. Legumes and Oilseed Crops I. - Berlin Heidelberg: Springer-Verlag, 1990. - P. 100-113.

6. Saxena M.C. Problems and potential of chickpea production in nineties. In Chickpea in the nineties: Proceedings of the second International Workshop on the chickpea Improvement, 4-8 Dec 1989, ICRISAT Center, Patancheru, India, 1990.

7. Булынцев С.В., Балашов А.В. Генетические ресурсы мировых коллекций нута // Вестник РАСХН. - 2010. - №6. - С. 42-45.

8. Мартьянова А.И. Зернобобовые: распространение, закупки, химический состав и ценность // Зерновые культуры. - 2001. - №1. - С. 24-25.

9. Лиманская В.Б., Шектыбаева Г.Х. Результаты конкурсного сортоиспытания сортов нута в засушливых условиях Западно-Казахстанской области // Межд. научнопрак. конф. - 2017. - С. 176-178.

10. Лиманская В.Б. Культура нута для очень континентальных условий Западного Казахстана // Вавилосвкие чтения - 2015: Сборник статей Международной научнопрактической конференции, посвященной 128-й годовщине со дня рождения академика Н.И. Вавилова. - Саратов, 2015. - С. 224-225.

DOI 10.18699/GPB2020-08

\title{
Идентификация генов устойчивости к стеблевой ржавчине в интрогрессивнх линиях яровой мягкой пшеницы селекции НИИСХ Юго-Востока с использованием молекулярных маркеров
}

Баранова O.A. ${ }^{1}$ к.б.н., в.н.с.; Сибикеев C.H. ${ }^{2}$, Дружин A.E. ${ }^{2}$

${ }^{1}$ ФБНУ «Всероссийский научно-исследовательский институт защчить растений», Санкт-Петербург, Россия;

${ }^{2}$ ФГБНУ «Научно-исследовательский институт сельского хозяйства юговостока» (НИИСХ Юго-Востока), Саратов, Россия.

*e-mail: baranova_oa@mail.ru

В работе проанализированы 73 интрогрессивные линии яровой мягкой пшениць на устойчивость к льсогорской, казанской и омской популяциям стеблевой ржавчины и наличие известных $\mathrm{Sr}$ генов. В проанализированных интрогрессивных линиях идентифицированы гень Sr31/Lr26, Sr25/Lr19, Sr28, Sr22, Sr35, Sr57/Lr34 и Sr38/Lr37. Сочетание генов Sr31+Sr25 было идентифицировано у 6 линий (8,2\%). У семи линий идентифицировано сочетание генов $S r 25+S r 28$, у двух линий - Sr25+Sr35. B трех разных линиях идентифициированы сочетания генов - Sr25+Sr31+Sr57, 
$\operatorname{Sr} 31+\operatorname{Sr} 28+\operatorname{Sr} 38$ u $\operatorname{Sr} 25+\operatorname{Sr} 57+\operatorname{Sr} 38$.

Ключевые слова: яровая мягкая пшеница, интрогрессивные линии, Puccinia graminis f. sp. tritici, $\mathrm{Sr}$ гены.

\section{Identification of the stem rust resistance genes in introgression lines of spring bread wheat of ariser breeding by using molecular markers}

Baranova O.A. ${ }^{1}$, Sibikeev S.N. ${ }^{2}$, Druzhin A.E. ${ }^{2}$

${ }^{1}$ All-Russian Institute of Plant Protection (FSBSI VIZR), St. Petersburg-Pushkin, Russia,baranova_oa@mail.ru. ${ }^{2}$ Agricultural Research Institute for the SouthEast Region (ARISER), Saratov, Russia.

The 73 spring bread wheat introgressive lines have been analyzed for resistance to Lysogorsk, Kazan and Omsk stem rust populations and for the presence of known Sr-genes. Sr31/Lr26, Sr25/Lr19, Sr28, Sr22, Sr35, Sr57/Lr34 and Sr38/Lr37 genes were identified in the analyzed introgressive lines. The combination of Sr31+Sr25 genes was identified in the six lines (8.2\%). The combination of Sr25 + Sr28 genes was identified in seven lines, Sr $25+$ Sr35 in two lines. In the three different lines the combinations - Sr $25+\operatorname{Sr} 31+\operatorname{Sr} 57, \operatorname{Sr} 31+\operatorname{Sr} 28+\operatorname{Sr} 38$ and $\operatorname{Sr} 25+\operatorname{Sr} 57+$ Sr 38 were identified.

Key words: spring bread wheat, introgression lines, Puccinia graminis $f$. sp. tritici, Sr-genes.

В последние годы наблюдается усиление вредоносности стеблевой ржавчины Puccinia graminis f. sp. tritici Eriks. \& Henn на территории Российской Федерации: эпифитотийное развитие болезни отмечалось в 2015-2019 годах в Западной Сибири и Нижнем Поволжье. Сохраняется угроза проникновения в РФ высоковредоносной расы возбудителя стеблевой ржавчины Ug99. В связи с этим большое значение приобретает оценка генетического потенциала селекционного материала пшеницы и идентификация генов устойчивости, эффективных не только против местных популяций патогена, но и против расы Ug99.

Целью нашей работы была оценка интрогрессивных линий пшеницы на устойчивость к стеблевой ржавчине и идентификация эффективных $\mathrm{Sr}$ генов с использованием молекулярных маркеров.

В работе анализировали селекционный материал НИИСХ Юго-Востока (73 интрогрессивных линий). Размножение популяций P. graminis и оценку устойчивости в лабораторных условиях проводили по методикам, принятым в мировой практике [2]. Тип реакции определяли по стандартной шкале [10]. ДНК выделяли из 5-ти дневных проростков с использованием цетилтриметиламмониумбромида (СТАВ) [7]. Разделение продуктов амплификации проводили в $2 \%$ агарозных гелях, окрашенных бромистым эти- 
дием. Положительным контролем служили изогенные линии и сорта с известными $S r$ - генами, негативным контролем - восприимчивый сорт Хакасская. Для идентификации генов устойчивости $(S r 2, S r 22, S r 24, S r 25, S r 26$, $\operatorname{Sr} 28, \operatorname{Sr} 31, \operatorname{Sr} 32, \operatorname{Sr} 35, \operatorname{Sr} 36, \operatorname{Sr} 38$ и $S r 57)$ использовали ДНК маркеры, рекомендованные для маркер вспомогательной селекции (MAS): $S r 2$-csSr2 [4], Sr22 - Xbarc121 [13], Sr24/ Lr24 -Sr24\#12 и Sr24\#50 [6], Sr25/Lr19 - Gb [8], Sr26 - Sr26\#43 [6], Sr28 - wPt-7004-PCR [9], Sr31/Lr26 - Scm9 [12], Sr32 csSr32\#2 [5], Sr35 - Xcfa2170 [14], Sr36 - Xstm773-2 [11], Sr38/Lr37 VENTRIUP-LN2 [1], Sr57/Lr34 - csLV34 [3].

На первом этапе работы 73 линии были оценены на устойчивость к трем популяциям стеблевой ржавчины на стадии проростков в лабораторных условиях. К казанской популяции патогена были устойчивы 32 линии (из них 8 гетерогенны по устойчивости), к лысогорской популяции были устойчивы 25 линий (из них 14 гетерогенны) и к омской популяции P. graminis были устойчивы 54 линии из 73. Только 10 линий $(13,7 \%)$ были устойчивы ко всем, взятым в анализ популяциям патогена.

Из генов, неэффективных к Ug99, но эффективных к местным популяциям стеблевой ржавчины в линиях был идентифицирован ген $\operatorname{Sr} 31$. Для его идентификации был использован маркер scm9, выявляющий ржаную транслокацию 1BL.1RS, несущую комплекс генов устойчивости к стеблевой $S r 31$, бурой $\operatorname{Lr26}$, желтой $\operatorname{Yr} 9$ ржавчинам и мучнистой росе $P m 8$. Данная транслокация (ген $S r 31$ ) была идентифицирована у 7 линий из 73 (9,6 \% образцов). Пять линий, несущих транслокацию 1BL.1RS, были устойчивы ко всем, взятым в анализ, популяциям патогена. Две линии были гетерогенны по данной транслокации. Ген $S r 38$ был идентифицирован в трех линиях с использованием праймеров VENTRIUP-LN2. Из генов, эффективных к $\mathrm{Ug} 99$, практически у всех линий (в 56 линиях), с использованием рекомендованного для маркер вспомогательной селекции маркера $G b$ идентифицирован ген $S r 25$ (76,7 \% линий). В девяти линиях с использованием маркера $w P t-7004-P C R$ был идентифицирован ген $S r 28$, однако данный факт будет подтверждаться с использованием других маркеров. Ген возрастной устойчивости $S r 57 / \operatorname{Lr} 34$ был идентифицирован в 11 линиях. Кроме того, в двух линиях ([Л503/ Sr35] и [Л503/ Sr35*4//Л503]) с помощью маркера Xcfa 2170 было подтверждено наличие $\operatorname{Sr35}$, а в линии [Фаворит/ W3534//Фаворит] с использованием маркера Xbarc121 подтверждено наличие гена $S r 22$. Для идентификации гена возрастной устойчивости $S r 2$ был использован CAPS маркер $c s S r 2$. Продукт амплификации с праймерами $c s S r 2 F / R$ наблюдался практически у всех взятых в анализ образцов. После рестрикции продукта амплификации рестриктазой $B s p H I$, диагностический фрагмент 172 п.о. наблюдали только в контрольных сортах Arthur и Oasis. Несмотря на наличие в родословных интрогрессивных линий доноров генов $S r 24$ и $S r 26$ в образцах эти гены не были идентифицированы, также не были обнаружены 
гены $S r 36$ и $S r 32$. Таким образом, в проанализированных интрогрессивных линиях был в основном идентифицирован ген $S r 25$. Сочетание генов $S r 31+S r 25$ было идентифицировано у 6 линий $(8,2 \%)$. У семи линий идентифицировано сочетание генов $S r 25+S r 28$, у двух линий $-S r 25+S r 35$. В трех разных линиях идентифицированы сочетания генов - Sr25+Sr31+Sr57, $\operatorname{Sr} 31+\operatorname{Sr} 28+\operatorname{Sr} 38$ и $\operatorname{Sr} 25+\operatorname{Sr} 57+\operatorname{Sr} 38$. Гены $\operatorname{Sr} 2, \operatorname{Sr} 24, \operatorname{Sr} 26, \operatorname{Sr} 32$ u $\operatorname{Sr} 36$ в анализируемых линиях обнаружены не были.

Благодарности: Работа выполнена при поддержке гранта РФФИ № 18-016-00170 а.

\section{Список литературы}

1. Helguera M. PCR assays for the Lr37-Yr17-Sr38 cluster of rust resistance genes and their use to develop isogenic hard red spring wheat lines / Helguera M., Khan I.A., Kolmer J., et al. // Crop Science - 2003. - V.43. - P. 1839-1847.

2. Jin, Y. Characterization of seedling infection types and adult plant infection responses of monogenic Sr gene lines to race TTKS of Puccinia graminis f. sp. Tritici / Jin, Y., Singh, R. P., Ward, R. W., et al. // Plant Disease - 2007. - V.91. - P. 1096-1099.

3. Lagudah E.S. Molecular genetic characterization of the Lr34/Yr18 slow rusting resistance gene region in wheat / Lagudah E.S., McFadden H., Singh R.P. et al. // Theor. Appl. Genet. - 2006. - V.114. - P. 21-30.

4. Mago R. An accurate DNA marker assay for stem rust resistance gene $S r 2$ in wheat / Mago R., Simkova, Brown-Guedira H.G., et al. // Theor. Appl. Genet. - 2011. V.122. - P. 735-744. DOI:10.1007/s00122-010-1513-4.

5. Mago R. Development of wheat-Aegilops speltoides recombinants and simple PCR-based markers for $\mathrm{Sr} 32$ and a new stem rust resistance gene on the 2S\#1 chromosome / Mago R., Verlin D., Zhang P., et al. // Theor. Appl. Genet. - 2013. - V.126. - P. 2943-2955.

6. Mago R. Development or PCR markers for the selection of wheat stem rust resistance genes Sr24 and Sr26 in diverse wheat germplasm / Mago R., Bariana H.S., Dundas I.S., et al.// Theor. Appl. Genet. - 2005. - V.111. - P. 496-504.

7. Murray M.G. Rapid isolation of high molecular weight plant DNA / Murray M.G., Thompson W.F. // Nucleic Acids Res. - 1980. - V. 8(19). - P. 4321-4326. DOI:10.1093/nar/8.19.4321.

8. Prins R. AFLP and STS tagging of $\operatorname{Lr} 19$, a gene conferring resistance to leaf rust in wheat / Prins R., Groenewald J. Z., Marais G. F., et al. // Theor. Appl. Genet. - 2001. V.103. - P. 618-624.

9. Rouse M.N.Identification of markers linked to the race Ug99 effective stem rust resistance gene Sr28 in wheat (Triticum aestivum L.) / Rouse MN, Nava IC, Chao S, Anderson JA, Jin Y. // Theoretical and Applied Genetics - 2012. - V.125. - P. 877-885. DOI: $10.1007 / \mathrm{s} 00122-012-1879-6$

10. Stakman E.C.Identification of physiologic races of Puccinia graminis var. tritici / Stakman E.C., Stewart D.M., Loegering W.Q. // United States Department of AgricultureAgricultural Research Service - 1962. - E-617 (rev).

11. Tsilo T.J. Diagnostic microsatellite markers for detection of stem rustresistance gene Sr36 in diverse genetic backgrounds of wheat / Tsilo T.J., Jin Y., Anderson J.A. // Crop Sci. - 2008. - V.48. - P. 253-261.

12. Weng Y. PCR-based markers for detection of different sources of 1AL.1RS and 
1BL.1RS wheat-rye translocations in wheat background / Weng Y., Azhaguvel P., Devkota R.N., Rudd J.C. // Plant Breeding. - 2007. - V.126. - P. 482-486.

13. Yu L.X. Haplotype diversity of stem rust resistance loci in uncharacterized wheat lines / Yu L.X., Liu S., Anderson J.A., Singh R.P., et al. // Mol. Breeding. - 2010. -V. 26. - P. 667-680. DOI: 10.1007/ s11032-010-9403-7

14. Zhang W. Genetic maps of stem rust resistance gene Sr35 in diploid and hexaploid wheat / Zhang W., Olson E., Saintenac C. et al. // Crop Sci. - 2010. - V.50. - P. 24642474. DOI: $10.2135 /$ cropsci2010.04.0202

DOI 10.18699/GPB2020-09

\section{Создание генофонда скороспелых ремонтантных $F_{1}$ гибридов крупноплодной земляники (Fragaria $\times$ ananassa Duch.)}

Батурин С.О., к.б.н., н.с.

ФИЦ ИЦиГ СО РАН; СибФТИ СФНЦА РАН, Новосибирск, Россия. e-mail: SO_baturin@mail.ru

В южной части Западной Сибири у большинства ремонтантных сортов срок созревания ягоды составляет около 30 суток. Нами в экспериментах получены нейтральнодневные $F_{1}$ гибриды № 17/9-15-1 и № 17/9-17-3 с

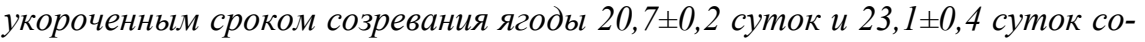
ответственно, а также гибриды с розовой окраской венчика № 16/5-30-5 и

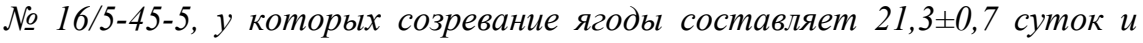

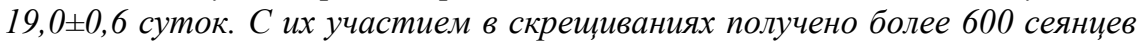
для отбора наиболее эффективных комбинаций скрещуивания для получения скороплодных $F_{1}$ нейтральнодневных гибридов.

Ключевье слова: Fragaria $\times$ ananassa Duch, скороспелость, $F_{1}$ гибриды, генофонд, скрещивания, отбор.

\section{Creation of a gene pool of the fast ripening $F_{1}$ hybrids of garden strawberry (Fragaria $\times$ ananassa Duch.)}

Baturin Sergey Olegovich, Institute of Cytology and Genetics, Siberian Branch of Russian Academy of Sciences, Novosibirsk

In most everbearing strawberry varieties, when grown in the southern part of Western Siberia, the ripening period of the berry is about 30 days. In our experiments, we obtained day neutral $F_{1}$ hybrids №17/9-15-1 and №17/9-17-3 with a shortened berry ripening period of $20.7 \pm 0.2$ days and $23.1 \pm 0.4$ days, respectively, and also pink-flowering hybrids №16/5-30-5 and №16/5-45-5, which have berry ripening of $21.3 \pm 0.7$ days and $19.0 \pm 0.6$ days. We used these hybrids in crosses and got over 600 seedlings to select the most effective cross combinations 